\author{
М. Х. Гашев ${ }^{1}$, О. І. Лігоцький ${ }^{2}$, \\ Л. М. Печериця², А. В. Носовський ${ }^{2}$ \\ 'Державний комітет ядерного регулювання України \\ ${ }^{2}$ Державний науково-технічний центр з ядерної \\ та радіаційної безпеки
}

\section{Аналіз порушень в роботі АЕС України, які сталися протягом 2008 року}

Наведено аналіз потоку порушень, які сталися на АЕС України протягом 2008 року, за рядом напрямків, що характеризують експлуатаційну безпеку.

М. Х. Гашев, А. И. Лигоцкий, Л. М. Печерица, А. В. Носовский

\section{Анализ потока нарушений в работе АЭС Украины,} произошедших в 2008 году

Приведен анализ потока нарушений в работе АЭС Украины, произошедших в 2008 году, по ряду направлений, характеризующих эксплуатационную безопасность.
A

наліз порушень в роботі атомних електричних станцій (АЕС), що сталися протягом року, є складовою оперативного та технологічного аналізу порушень у роботі АЕС України, який щорічно (починаючи з 1993 р.) проводиться спеціалістами Державного підприємства «Державний науково-технічний центр з ядерної та радіаційної безпеки» (ДНТЦ ЯРБ) у рамках науково-дослідної роботи (НДР). Статистичні дані, отримані в результаті цього аналізу, дозволяють проводити як кількісну, так і якісну оцінку рівня експлуатаційної безпеки, простежувати тенденції щодо ії̈ негативних або позитивних змін, виявляти проблеми у забезпеченні належного рівня безпечної експлуатації, а також у забезпеченні та підтримці рівня культури безпеки. Крім того, завдяки накопиченню даних за попередні роки відкривається можливість проводити порівняння даних щодо кількості порушень в роботі АЕС, їх причин, розподілу за низкою критеріїв з аналогічними даними попередніх років.

Актуальність проведення аналізу порушень у роботі АЕС України зумовлена необхідністю оцінки поточного рівня експлуатаційної безпеки українських АЕC та спрямована в цілому на запобігання виникнення подій, підвищення ефективності використання досвіду експлуатації та підвищення рівня експлуатаційної безпеки АЕС.

У даній роботі використано методики експертної оцінки, статистичної обробки даних та аналізу корінних причин. У статті наведено аналіз порушень, які сталися протягом 2008 р., за рядом напрямків, які характеризують експлуатаційну безпеку, та надано рекомендації щодо удосконалення системи організації розслідування порушень в роботі АЕC і оптимізації системи зворотного зв'язку від досвіду експлуатації.

\section{Статистична оцінка порушень у роботі АЕС України}

У 2008 р. в Україні на 15 енергоблоках АЕС, що перебували у промисловій експлуатації, та на трьох енергоблоках Чорнобильської АЕС (з реакторами великої потужності канальними - РВПК), що працювали в режимі припинення експлуатації, сталося 22 порушення [1], зокрема:

на Запорізькій АЕС (ЗАЕС, 6 енергоблоків) - 5;

на Рівненській АЕC (РАEC, 4 енергоблоки) - 7;

на Хмельницькій АЕС (ХАЕС, 2 енергоблоки) - 5; на Чорнобильській AЕС (ЧАЕС, 3 енергоблоки) - 0;

на Южно-Українській АЕС (ЮУАЕС, 3 енергоблоки) - 5.

Потік порушень - середня кількість порушень на один енергоблок - у роботі АЕС України за останні 5 років представлено на рис. 1.

Цей показник у 2008 р. є найнижчим серед показників останніх п'яти років (22 порушення в роботі AEC на 18 енергоблоків), а середнє його значення за 2004-2008 pp. дорівнює 1,7 (жирна пряма на рис. 1).

Динаміку кількості порушень у роботі АЕС України за останні п'ять років наведено на рис. 2.

Останні три роки загальна кількість порушень поступово зменшується: у 2008 р. порівняно з 2007 р. - на $12 \%$, порівняно з 2006 р. - на $33 \%$, і $є$ найменшою за останні п'ять років.

Розподіл потоку порушень по майданчиках АЕС України наведений на рис. 3. У 2008 р. зменшилася кількість порушень на ЗАЕС та РАEC у порівнянні з минулим роком. На ЮУАЕС цей показник залишається незмінним протягом 


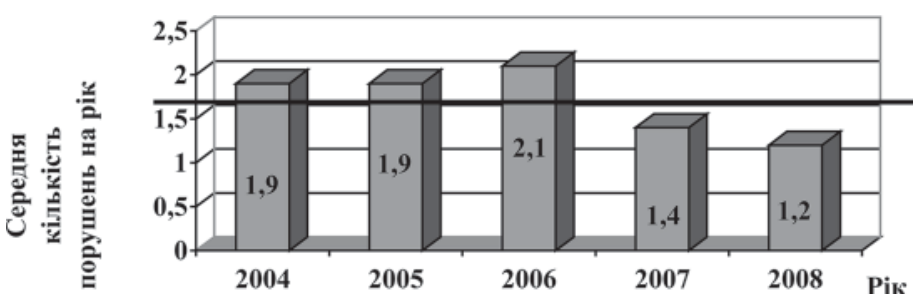

Рис. 1. Потік порушень

у роботі АЕС України в 2004-2008 pp.

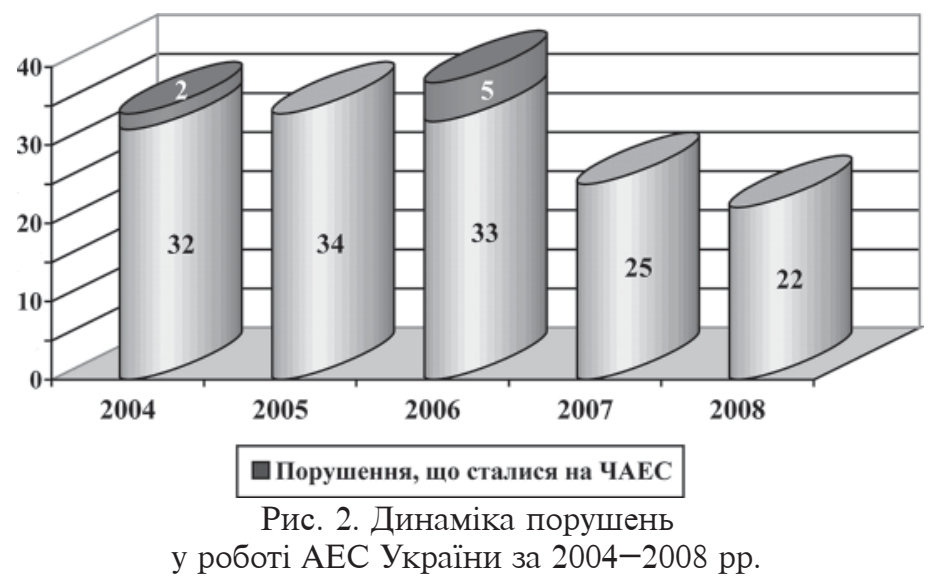

останніх п'яти років. На ХАЕС у 2008 р. зафіксовано на одне порушення більше, ніж у минулому році. Як у 2007, так і у 2008 р. на ЧАЕС не сталося жодного порушення.

Кількість порушень у перерахунку на один енергоблок залишається найвишою на XАEC (2,5 порушення на енергоблок). Керівництву ХАЕС слід звернути увагу на цей факт, проаналізувати його причини та вжити відповідних заходів.

Найбільша кількість порушень, які сталися протягом 2008 р., припадає на енергоблоки № 3 РАEC, № 2 ХАЕС (по 4 порушення на кожний енергоблок); № 4 ЗАЕС, № 3 ЮУАЕС (по 3 порушення).

Серед діючих енергоблоків жодного порушення не зафіксовано на енергоблоках №№ 1, 3, 6 ЗАЕС та № 1 ЮУАЕС.

Розподіл порушень для окремих типів реакторних установок (РУ) діючих енергоблоків (рис. 4) демонструє, що середня кількість порушень на енергоблок з водо-водяними енергетичними реакторами типу ВВЕР-1000 збільши-

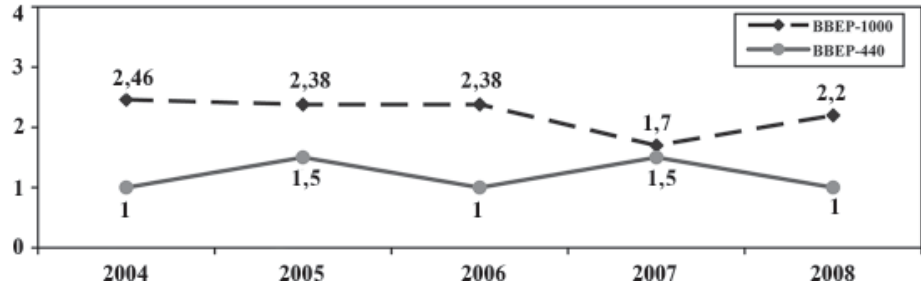

Рис. 4. Розподіл середньої кількості порушень на блок за типами реакторних установок

лась (у 1,3 раза) порівняно з 2007 р., а з реакторами типу ВВЕР-440 - зменшилась (у 1,5 раза).

У 2008 р. порушень меж та умов безпечної експлуатації на АЕC України не зареєстровано.

У звітному році не сталося жодного порушення, які за Міжнародною шкалою ядерних подій International Nuclear Event Scale (INES) [3] класифікуються рівнем «1» - «відхилення від дозволеного режиму експлуатації, що зумовлені відмовою обладнання, помилками персоналу або процедурними невідповідностями». 3 усіх порушень в роботі АЕС України у 2008 р. 77 \% мали рівень «0» (не суттєво для безпеки), $23 \%$ рівень «поза шкалою» (рис. 5). Зазначимо, шо в 2007 р. рівнем «0» за шкалою INES класифіковано $68 \%$ порушень.

Розподіл кількості порушень у роботі АЕС України, що сталися протягом 2004-2008 рр., за шкалою INES представлено на рис. 6.

Розподіл порушень у роботі АЕС України за наслідками наведено на рис. 7.

Як і в попередні роки, переважна більшість порушень (68\% загальної кількості) у роботі АЕС у 2008 р. була пов'язана із зупиненням РУ, відключенням енергоблока від мережі чи розвантаженням РУ (категорії П05 та П08 за [1]).

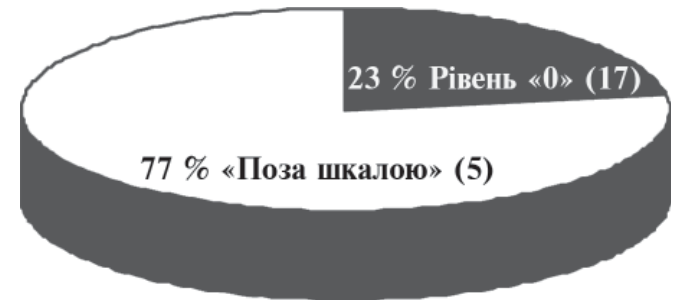

Рис. 5. Розподіл порушень у роботі AEC за шкалою INES у 2008 р.

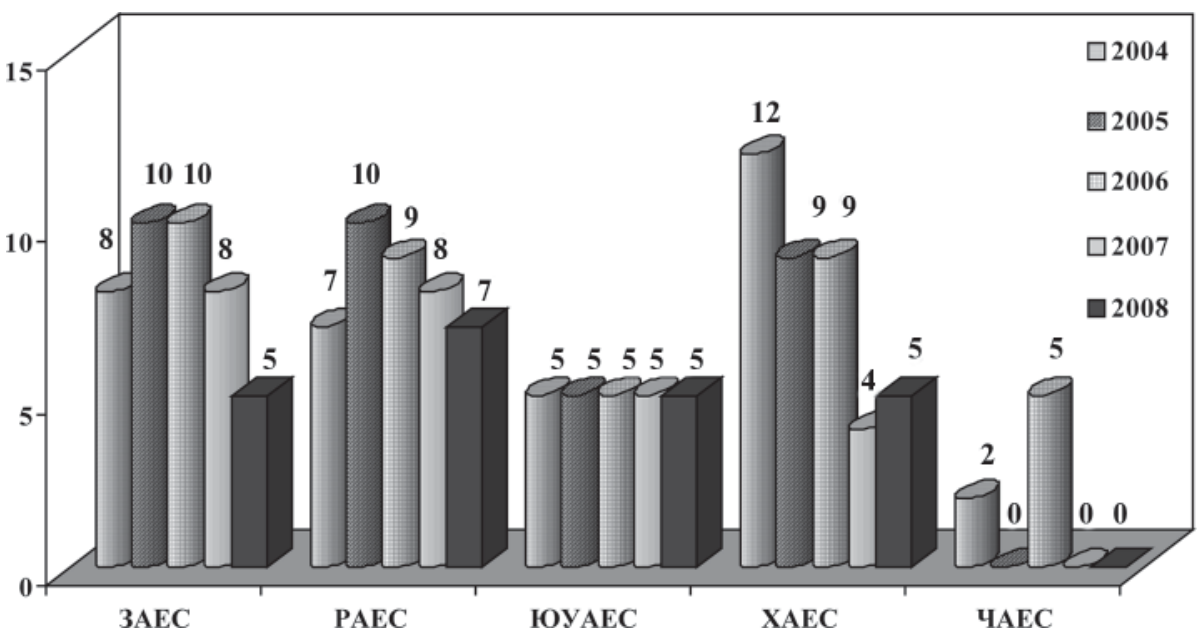

Рис. 3. Розподіл порушень по майданчиках АЕС у 2004-2008 pp. 


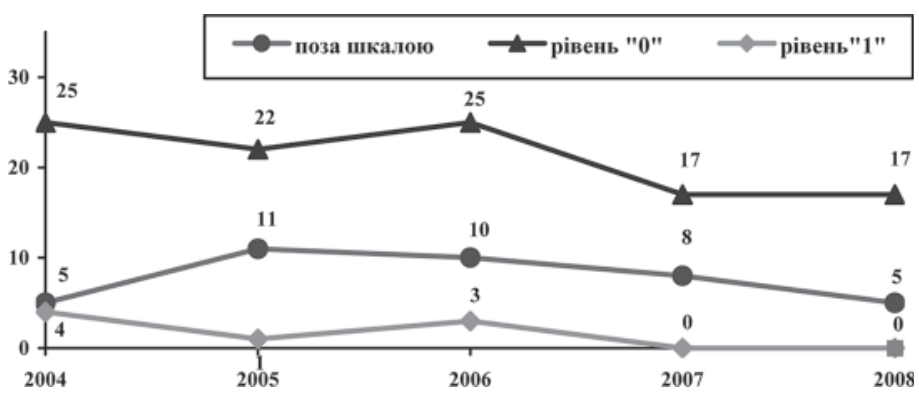

Рис. 6. Розподіл кількості порушень у роботі АЕС України за шкалою INES, 2004-2008 pp.

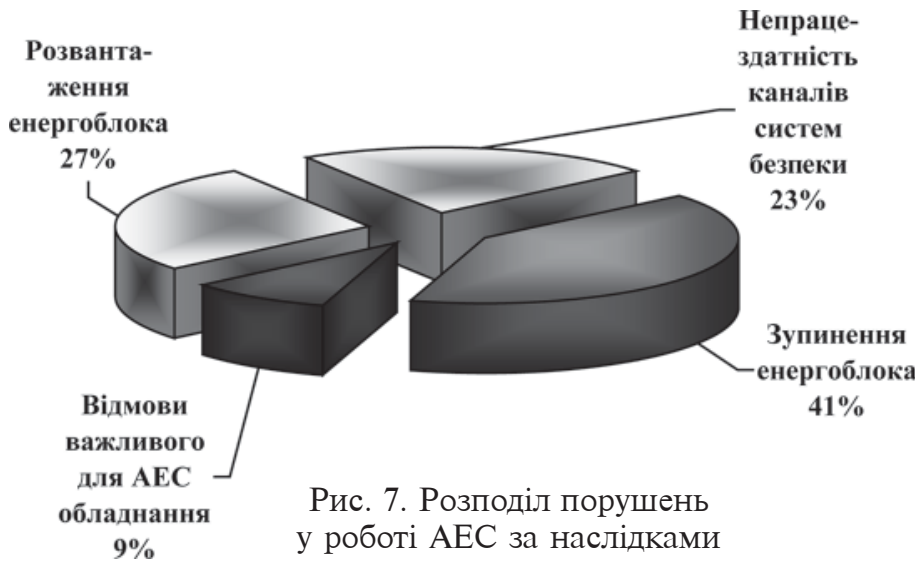

У двох випадках (на блоках № 3 РАЕС та № 2 ХАЕС) сталися порушення, пов'язані з відмовою важливого для безпеки АЕС обладнання та трубопроводів (категорія П07). Значна частина (23\%) порушень спричинилася через непрацездатність каналу (каналів) систем безпеки протягом терміна, що не перевищує дозволений Технологічним регламентом (категорія П10). У 2008 р. цей показник зріс порівняно з 2007 р. (категорію П10 у 2007 р. мали $12 \%$ порушень).

Під час 22 порушень у роботі АЕС України було зафіксовано 30 аномальних подій. Основними факторами, що зумовили їх виникнення, є відмови обладнання (рис. 8). Кількість аномальних подій, що виникли через недоліки процедур, збільшилася з $6 \%$ у 2007 р. до $10 \%$ у 2008 р. Дві аномальні події (7 \% загальної кількості) сталися 08.05.08 р. під час порушення в роботі енергоблока № 2 ЮУАЕС (звіт № 2 ЮУК-П05-03-05-08) через помилки персоналу (в 2007 р. таких подій не зафіксовано).

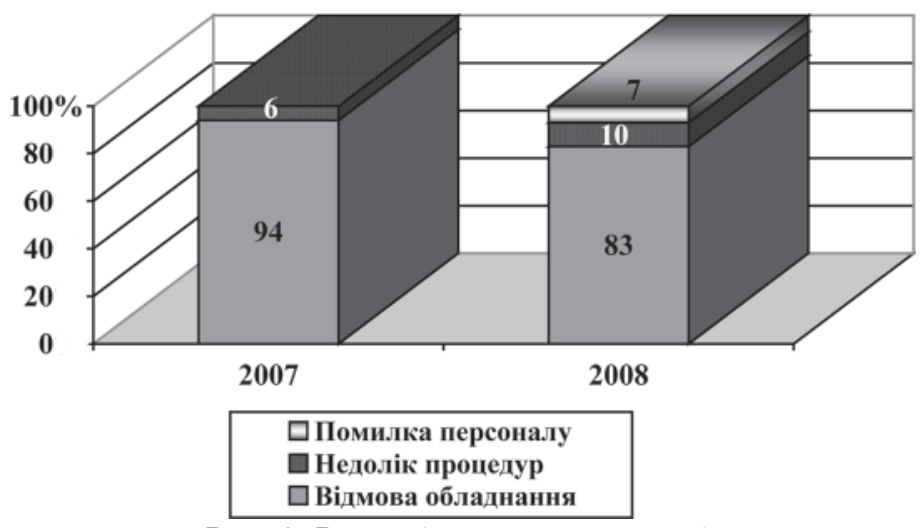

Рис. 8. Розподіл аномальних подій

за факторами, що обумовили їх виникнення
У 2008 р. спостерігається майже рівномірний розподіл між порушеннями, шо були викликані відмовами обладнання (рис. 9):

основних систем - 10 порушень, або $32,25 \%$ загальної кількості (у 2007 р. - $50 \%$ );

систем безпеки (СБ) - 11 порушень, або $35 \%$ (у 2007 р. $32,4 \%)$

допоміжних систем - 10 порушень, або 32,25 \% (у 2007 р. $17,6 \%)$

Отже, значно зменшилася кількість відмов основних систем, але внески відмов обладнання систем безпеки та допоміжних систем зросли. Серед систем безпеки найбільше відмов зафіксовано в системі управління захисними діями систем безпеки (три аномальні події, пов'язані з відмовою цієї

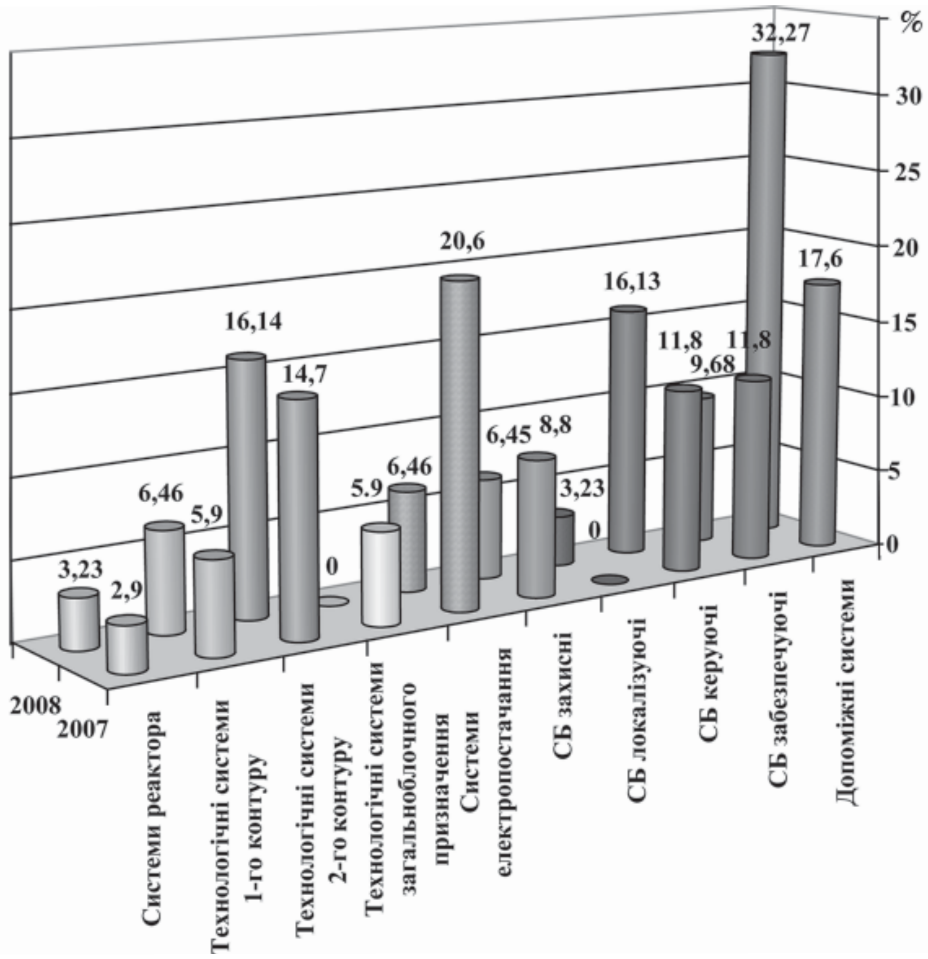

Рис. 9. Розподіл порушень

за системами, шо відмовили

системи) та по дві аномальні події, викликані відмовами в органах управління і захисту реактора, автоматиці системи управління і захисту реактору, системі надійного електропостачання споживачів власних потреб змінного струму (1 група надійності).

Найбільша кількість відмов серед систем припадає на: допоміжні системи - 32,25\% (2007 p. - 17,6\%);

технологічні системи 2-го контуру - $16 \%$ (2007 р. - 14,7\%); систему управління захисними діями систем безпеки 9,68\% (2007 p. $-5,88 \%)$.

Значно зменшилася, у порівнянні з минулим роком, кількість відмов систем електропостачання: якщо в 2007 р. внесок у загальну кількість таких відмов становив 20,6\%, то в 2008 р. - 6,5\% (два порушення). Проте зросла кількість відмов технологічних систем 2-го контуру та системи управління захисними діями систем безпеки. Серед допоміжних систем, на які припадає $32,25 \%$ усіх відмов, найбільша кількість відмов спостерігалася в ланцюгах управління, захисту і сигналізації (6 порушень, або 19,35 \% загальної кількості порушень). 

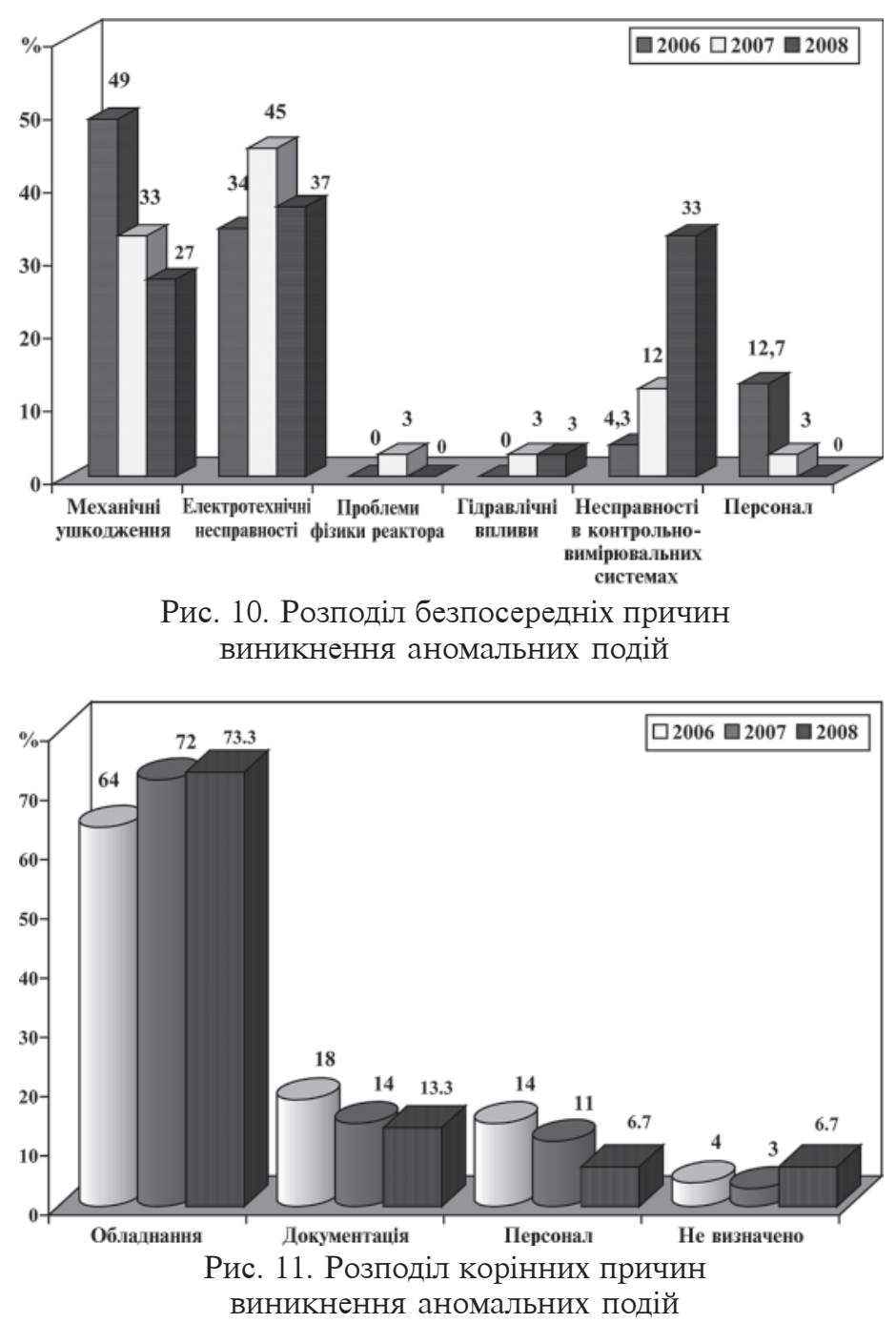

Крім того, якщо в 2007 р. на відмови елементів електронної схеми, логічного блока та реле припадала п'ята частина усіх відмов обладнання, то в 2008 р. кількість таких відмов зросла до $28 \%$.

Розподіл безпосередніх та корінних причин виникнення аномальних подій за їх типами наведено на рис. 10 та 11.

Серед безпосередніх причин аномальних подій можна виділити дві великі групи, яким традиційно належать перші місця: механічні ушкодження та несправності в електротехнічній частині. Однак останні три роки простежується тенденція до збільшення кількості безпосередніх причин, викликаних несправностями у контрольно-вимірювальних системах:

хибний сигнал - 6 з 30 причин;

неправильне показання параметра - 4 з 30 причин.

Отже, необхідно проаналізувати причини такого збільшення відмов обладнання контрольно-вимірювальних систем, ефективність, повноту та достатність заходів, що впроваджуються.

Серед корінних причин аномальних подій відповідно до словнику кодів [1] можна виділити три основні групи, пов'язані: з обладнанням; документацією; персоналом. Розподіл корінних причин за цими групами наведено на рис. 11.

Як і в минулі роки, найбільша частина (73,3\% у 2008 р.) корінних причин виникнення аномальних подій пов'язана з обладнанням. При цьому кількісно ця група останні три роки поступово збільшується, а групи, пов’язані з докумен- тацією та персоналом, навпаки, зменшуються. Зазначимо, що в 2008 р. зросла кількість порушень, корінні причини яких не встановлені. Ці порушення сталися на енергоблоці № 2 ХАЕС (звіти № 2ХМЕ-П07-01-02-08 - відмова органа регулювання системи управління та захисту реактору (СУЗ) та № 2ХМЕ-П10-04-7-08 - непрацездатність 3-го каналу забезпечуючої СБ через відмову на включення генераторного вимикача).

Серед корінних причин, пов'язаних з обладнанням, найбільший внесок склали недоліки конструювання (12 аномальних подій, або майже $39 \%$ загальної кількості) та недоліки проектування (6 аномальних подій, або $19 \%$ ), тобто разом $58 \%$ усіх аномальних подій. Усі 4 аномальні події, або 13,3\%, корінними причинами яких були недоліки документації, відбулися через недоліки станційної програми контролю за виявленням та усуненням непрацездатності систем (елементів).

\section{Аналіз причин порушень та призначених коригувальних заходів}

Після виникнення порушення в роботі АЕС комісія з розслідування проводить всебічний аналіз умов та причин виникнення порушення і призначає коригувальні заходи для усунення наслідків, а головне - причин виникнення порушення. В ідеалі результатом розслідування $\epsilon$ розробка саме таких коригувальних заходів, котрі усувають як безпосередню, так і корінну причину порушення та запобігають виникненню його в подальшому. Тому дуже важливо правильно визначити всі причини та фактори, що сприяли виникненню порушення.

Реально відбувається так, шо порушення повторюються з тих самих причин і навіть на тому ж самому обладнанні. Це говорить про низьку якість розслідування порушення, яка виразилася в неправильному визначенні причин порушення або призначенні неадекватних коригувальних заходів. Саме питанню аналізу причин порушення та оцінці адекватності коригувальних заходів, а також оцінці роботи станційної комісії з розслідування порушення й приділяється основна увага під час проведення оперативного та технологічного аналізу порушень в роботі АEC, який регулярно виконується в ДНТЦ ЯРБ. Крім того, розробляються пропозиції щодо використання результатів розслідування в рамках системи зворотного зв'язку від досвіду експлуатації.

Для оцінки адекватності коригувальних заходів використовуються такі критерії:

правильність визначення корінної причини аномальної події;

ефективність призначеного коригувального заходу;

мінімальний термін виконання коригувального заходу; можливість реалізації запропонованого коригувального заходу;

відсутність аналогічних порушень у роботі АЕС після впровадження коригувального заходу.

Результати аналізу правильності визначення причин порушень та адекватності призначених коригувальних заходів для 22 порушень у роботі AEC, які сталися протягом 2008 р., у порівнянні з аналогічними даними за 2004-2007 pp. наведено в табл. 1.

У 2008 р. більше половини від загальної кількості склали порушення, для яких правильно визначено їх причини та призначено відповідні коригувальні заходи. Цей показник покращився порівняно з попереднім роком на $11 \%$. Більш як для чверті порушень причини визначено неправильно, 
Таблиия 1. Результати аналізу правильності визначення причин порушень та адекватності призначених коригувальних заходів

\begin{tabular}{|c|c|c|c|c|c|}
\hline Погазник & $2004 \mathrm{p}$. & $2005 \mathrm{p}$. & $2006 \mathrm{p}$. & $2007 p$ & $2008 \mathrm{p}$. \\
\hline Загальна кількість проаналізованих порушень у роботі АЕС & $\begin{array}{l}34 \\
100 \%\end{array}$ & $\begin{array}{l}34 \\
100 \%\end{array}$ & $\begin{array}{l}38 \\
100 \%\end{array}$ & $\begin{array}{l}25 \\
100 \%\end{array}$ & $\begin{array}{l}22 \\
100 \%\end{array}$ \\
\hline $\begin{array}{l}\text { Кількість порушень у роботі АEC, для яких правильно визначено } \\
\text { причини та призначено адекватні коригувальні заходи }\end{array}$ & $55,9 \%$ & $52,9 \%$ & $26,3 \%$ & $\begin{array}{l}12 \% \\
48 \% \\
\end{array}$ & $\begin{array}{ll}13 \\
59 \% \\
\end{array}$ \\
\hline $\begin{array}{l}\text { Кількість порушень у роботі АЕС, для яких неправильно } \\
\text { визначено причини }\end{array}$ & $\begin{array}{l}4 \\
11.8 \%\end{array}$ & $\begin{array}{l}4 \\
11,8 \%\end{array}$ & $\begin{array}{ll}13 \\
34,2 \%\end{array}$ & $\begin{array}{l}7 \\
28 \%\end{array}$ & $\begin{array}{l}6 \\
27 \%\end{array}$ \\
\hline $\begin{array}{l}\text { Кількість порушень у роботі АЕС, для яких призначено формальні } \\
\text { коригувальні заходи }\end{array}$ & 4 & $\begin{array}{l}7 \\
20,6 \%\end{array}$ & $\begin{array}{l}11 \% \\
29 \%\end{array}$ & 3 & $\begin{array}{l}0 \\
0 \%\end{array}$ \\
\hline $\begin{array}{l}\text { Кількість порушень у роботі АЕС, для яких неможливо оцінити } \\
\text { адекватність коригувальних заходів }\end{array}$ & $\begin{array}{ll}11 \\
32,3 \%\end{array}$ & $\begin{array}{ll}12 \\
35,3 \%\end{array}$ & $\begin{array}{ll}15 \\
39,5 \%\end{array}$ & $\begin{array}{ll}3 \\
12 \%\end{array}$ & $\begin{array}{ll}3 \\
14 \%\end{array}$ \\
\hline
\end{tabular}

а це призводить до призначення малоефективних коригувальних заходів, які не спроможні запобігти виникненню аналогічних порушень у майбутньому. Порівняно з 2007 р. на $2 \%$ збільшилася кількість порушень, для яких неможливо оцінити адекватність коригувальних заходів через неповноту інформації, наведену у звіті з розслідування порушення.

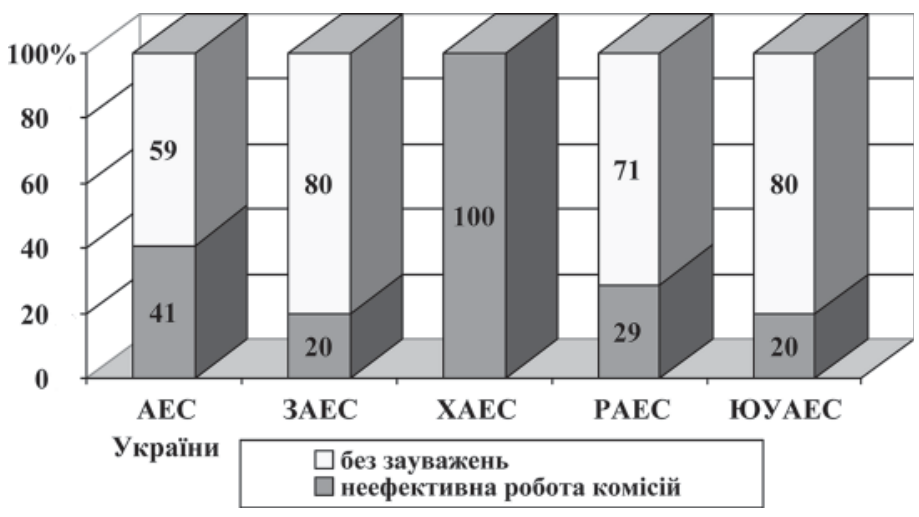

Рис. 12. Порівняльний аналіз

ефективності роботи станційних комісій

Проведена за результатами оперативного аналізу (рис. 12) оцінка ефективності роботи станційних комісій показала, що $41 \%$ порушень у роботі всіх АЕС, що сталися протягом 2008 р., розслідувано не належним чином, і звіти про ці порушення мали зауваження до роботи станційних комісій. Найкращий показник якості розслідування - на PAEC (71\% звітів про порушення без зауважень), найгірший - на ХАЕС (в усіх звітах про розслідування порушення є суттєві зауваження). Основні виявлені недоліки роботи комісій - неправильне визначення аномальних подій, корінних причин порушень, призначення неадекватних коригувальних заходів. Їнформація про порушення надається не в повному обсязі, не відповідає вимогам [1], призначені коригувальні заходи є неповними, що неодмінно призводить до виникнення аналогічних порушень.

\section{Аналіз причин повторюваності порушень}

Останніми роками кількість порушень на АЕС України постійно знижується. При цьому в середньому половина від усієї кількості порушень повторюються. Аналіз повторюва- них подій показав, що розслідування станційними комісіями проводиться формально, визначаються не всі фактори, які мають безпосередній вплив на виникнення порушень.

На підставі інформації, представленої в звітах про розслідування порушень, з 22 порушень у роботі АЕС за 2008 р. 9 відбувалися раніше (з них два повторилося вже в поточному році).

Найбільше повторюваних порушень сталося на ЗАЕС та ЮУАЕС - по три, що становить більше половини від загальної кількості подій на кожній із зазначених АЕС і свідчить про неефективне використання зворотного зв'язку від досвіду експлуатації на цих АЕС.

Не завжди правильність визначення причин порушення очевидна. Саме повторне виникнення аналогічного порушення говорить про те, що причини були визначені неправильно або впроваджені коригувальні заходи виявилися неефективними. Отже, питання повторюваності порушень займає важливе місце в аналізі порушень взагалі.

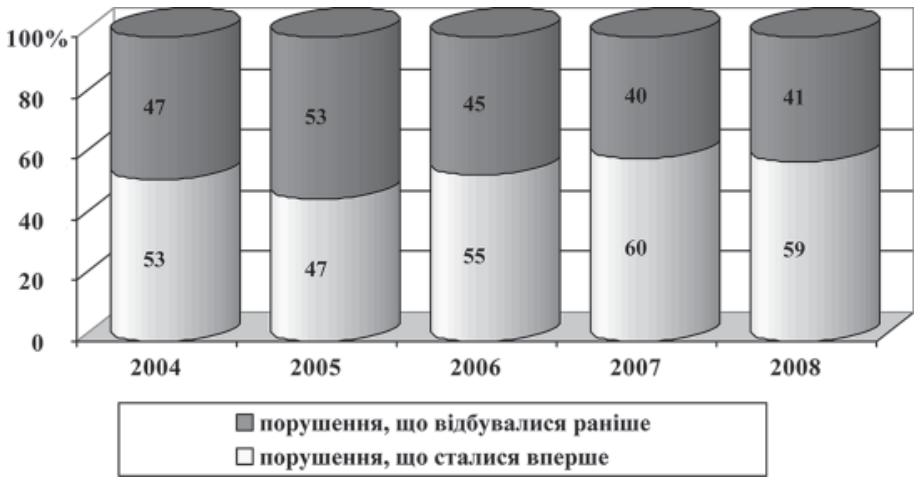

Рис. 13. Повторюваність порушень у роботі АЕC

Наведені на рис. 13 результати аналізу повторюваності порушень у роботі АЕС, шо відбулися за звітний період, у порівнянні з аналогічними даними 2004-2007 рр. отримано на підставі звітів про порушення в роботі AEC. Вони ілюструють стан використання досвіду експлуатації, а саме факт недостатньо ефективного засвоєння уроків з розслідування порушень у роботі АЕС. Кількість повторюваних порушень становить $41 \%$ загальної кількості порушень у 2008 р., а $9 \%$ загальної кількості порушень - ті, що повторилися у звітному році. Однак зазначимо, що жодного порушення у 2008 р. не повторилося на тому ж самому енергоблоці або навіть АЕС. Ця позитивна тенденція дає надію, що керівництво атомних станцій прикладає певних зусиль у цьому напрямку. 


\section{Статус реалізації коригувальних заходів}

Несвоєчасне впровадження запланованих коригувальних заходів може стати причиною повторення порушення в роботі АЕС незважаючи на те, що причини порушення були встановлені правильно, а призначені коригувальні заходи - адекватні.

Важливим питанням під час розробки коригувальних заходів є термін їх реалізації. 3 одного боку, цей термін має бути реалістичним з погляду на можливе впровадження таких заходів. 3 іншого боку, з метою запобігання повторювання порушень у роботі АЕС, необхідно встановлювати найменші терміни впровадження коригувальних заходів. Комісії з розслідування порушень у роботі АЕС повинні проводити оцінку цих аспектів і призначати оптимальні терміни для впровадження коригувальних заходів або розробляти додаткові коригувальні заходи на той час, поки не буде усунуто корінної причини

За даними аналізу інформації про впровадження коригувальних заходів у 2008 р. можна зробити висновок, що в цілому АЕС виконують коригувальні заходи, призначені за результатами розслідування порушень у роботі АЕС, але проблеми шодо дотримання термінів виконання деяких з них ще мають місце. Як правило, це стосується тих заходів, реалізація яких потребує залучення додаткових коштів. Ще одним фактором, який впливає на несвоєчасність впровадження коригувальних заходів, є потреба взаємодії АЕС з іншими організаціями (проектними, виробничими, ремонтними, науково-технічними тощо) та необхідність узгодження і затвердження прийнятих технічних рішень або змін в експлуатаційній документації з відповідними організаціями.

Ці фактори необхідно враховувати під час розробки коригувального заходу. Беручи до уваги, що термін його виконання може збільшитися, слід проаналізувати, як це може вплинути на безпечну експлуатацію АEC, та, за необхідністю, розробити компенсуючі заходи, які б зменшили негативний вплив. Досвід експлуатації показує, що невчасно впроваджені коригувальні заходи призводять до появи аналогічних порушень. Тому важливо дотримуватися графіка впровадження коригувальних заходів. Використання цих рекомендацій допоможе підтримувати належний рівень експлуатаційної безпеки.

\section{Висновки тарекомендації}

Під час виконання даної роботи проведено статистичну оцінку потоку порушень у роботі АЕС України за 2008 р. і виконано їх аналіз. За результатами статистичної оцінки та розподілів порушень треба відмітити:

1) середня кількість порушень на один енергоблок знизилася порівняно з минулим роком та $є$ найнижчою за останні п'ять років;

2) на АЕС України не зафіксовано жодного порушення, класифікованого рівнем «1» за шкалою INES;

3) переважна більшість порушень (68\%) пов'язана із зупиненням РУ, відключенням енергоблока від мережі чи розвантаженням РУ;
4) значно зросла кількість аномальних подій, шо виникли через несправності в контрольно-вимірювальних системах (33\% - 2008 р., $12 \%-2007$ р.);

5) до $41 \%$ звітів з розслідування порушень виявлені зауваження шодо якості розслідування;

6) останні роки відмічається незначне зниження кількості порушень в роботі АЕС України, що відбувалися раніше, однак цей показник $(41 \%)$ залишається ще досить високим;

7) станції в цілому вчасно впроваджують призначені коригувальні заходи, але існують проблеми щодо дотримання призначених термінів реалізації окремих з них;

8) необхідно звернути увагу на удосконалення системи організації розслідування порушень в роботі АЕС і оптимізацію системи зворотного зв'язку від досвіду експлуатації.

3 метою запобігання повторення порушень та зменшення загальної кількості порушень у роботі AEC необхідно:

1) усунути існуючі недоліки в організації управління і експлуатації AEC, зокрема забезпечити взаємозв'язок між підрозділами, що займаються безпосередньо розслідуванням порушень, та підрозділами, що займаються аналізом порушень, які відбуваються на інших АЕС України та світу;

2) впроваджувати сучасні методики аналізу порушень, які пройшли відповідну апробацію та рекомендовані Міжнародною агенцією з атомної енергії (МАГАТЕ);

3) провести на галузевому рівні всебічний комплексний аналіз порушень у роботі АЕС України, які мали місце протягом останніх років, і на його підставі розробити та надати до Держатомрегулювання рекомендації щодо попередження повторюваності порушень у роботі однотипних енергоблоків АЕС, підвищення якості розслідування та визначення корінних причин;

4) забезпечити впровадження галузевої системи обліку результатів розслідування порушень та моніторингу виконання коригувальних заходів по галузі в цілому;

5) проводити семінари з обміну досвідом щодо аналізу подій та призначення коригувальних заходів із залученням спеціалістів з боку експлуатуючої організації та Держатомрегулювання.

\section{Список літератури}

1. Положення про порядок розслідування та обліку порушень в роботі атомних електричних станцій (НП 306.2.100-2004). Затверджено наказом Держатомрегулювання від 1 грудня 2004 p. № 184 та зареєстровано в Міністерстві юстиції України 17.12.2004, за № $1594 \backslash 10193$.

2. Звіти про розслідування порушень у роботі АЕС України, що сталися протягом 2008 року.

3. IAEA-INES-ИНЕС. Международная шкала ядерных событий. Руководство для пользователей. - Вена: МАГАТЭ, 2001.

4. Звіт про науково-дослідну роботу «Оперативний та технологічний аналіз порушень в роботі АЕС України в 2007-2008 pр.». Етап заключний «Оперативний та технологічний аналіз порушень в роботі АЕС України за 2008 рік».

Надійшла до редакиії 06.06.2009. 